\title{
REFUGIADOS NO BRASIL: REFLEXÕES ACERCA DO PROCESSO DE INTEGRAÇÃO LOCAL
}

\author{
Julia Bertino Moreira*
}

\begin{abstract}
O artigo se propõe a refletir sobre o processo de integração dos refugiados no Brasil. Para tanto, inicia-se com a discussão acerca da categoria dos refugiados, tratada como um 'problema' que demanda soluções a serem implementadas por atores estatais e não-estatais. Em seguida, situa-se sucintamente o debate conceitual na literatura especializada acerca da integração, levantando-se diferentes perspectivas para compreendê-la. O enfoque dado ao processo de integração dos refugiados no Brasil se pautou pela estrutura institucional no país, pelos atores envolvidos nesse processo e pelas condições de vida dos refugiados. Ao final, lançam-se reflexões em torno desse processo, sobretudo em termos da necessidade de maior aprimoramento e efetividade da estrutura arquitetada no país, da atuação dos atores envolvidos, o que requer ainda maior participação dos próprios refugiados.
\end{abstract}

Palavras-chave: refugiados, integração local, Brasil.

\section{Refugiados como categoria: situando o 'problema'}

Os refugiados são considerados migrantes internacionais forçados, que cruzam as fronteiras nacionais de seus países de origem em busca de proteção. Eles fogem de situações de violência, como conflitos internos, internacionais ou regionais, perseguições em decorrência de regimes políticos repressivos, entre outras violações de direitos humanos. Questões étnicas, culturais e religiosas, desigualdade socioeconômica, altos níveis de pobreza e miséria e, sobretudo, instabilidade política estão no cerne dos fatores que levam às migrações de refugiados ${ }^{1}$.

A temática dos refugiados se encontra intrinsecamente associada à esfera do Estado-nação. Isso porque o país de origem ameaçou violar ou de fato violou ou, ainda, revelou-se incapaz de proteger os direitos de seus nacionais, o que os

Professora de Relações Internacionais na UFABC, vinculada à Cátedra Sérgio Vieira de Mello. Campinas, SP/Brasil.

1 LOESCHER, Gil. Beyond Charity: international cooperation and the global refugee crisis. 
levou a fugir para escapar da situação de violência. Nessa medida, a categoria dos refugiados emerge como consequência das ações ou omissões políticas empreendidas pelo Estado. Diante disso, o país acolhedor deve prover proteção a essa população estrangeira recebida em seu território e garantir direitos que estavam em risco no país de origem.

O vínculo jurídico-político do indivíduo ao Estado-nação, enquanto pertencimento a uma comunidade política, ainda se faz necessário, portanto, para o exercício e a concretização efetiva de direitos. Ao deixar seu país de origem e ingressar em outro país, para que a proteção estatal seja concedida e tal vínculo seja restabelecido, o indivíduo precisa ter reconhecido o estatuto de refugiado.

Como bem coloca Haddad², a categoria dos refugiados se define com referência ao Estado e não existiria sem o conceito de soberania e a relação entre Estado, cidadania e território. De um lado, a existência do sistema estatal, assentada na soberania, é o que torna inteligível a categoria dos refugiados. De outro, a prática de proteger, solucionar, incluir e excluir os refugiados é o que contribui para reafirmar a soberania e o sistema estatal, reproduzindo essa relação.

Os movimentos de refugiados impactam não apenas os Estados-nação, como também as relações internacionais, considerando que as migrações internacionais se dão entre Estados soberanos, organizados num sistema internacional. Esses deslocamentos operam a transferência de um indivíduo sob a jurisdição de um Estado para a de outro, o que gera mudança no pertencimento a uma comunidade política ${ }^{3}$.

O que alicerça, portanto, o acolhimento de refugiados pelos Estados gira em torno da fronteira erguida entre inclusão e exclusão, admissão e rejeição, desejáveis e indesejáveis; ao mesmo tempo, enseja vulnerabilidade, indefinição e incerteza a esses migrantes internacionais forçados. Tal fronteira separa aqueles que serão inseridos na ordem social, cultural, econômica e política estatal, aqueles que terão direito a ter direitos dos que não serão contemplados ${ }^{4}$.

Os refugiados são vistos como outsiders, à medida que vêm de fora; são estrangeiros, por não pertencerem à nação, por serem estranhos aos códigos compartilhados e informados pela identidade cultural, social, étnica, religiosa, linguística da comunidade de destino ${ }^{5}$. No embate da relação de alteridade, materializada pelos limites construídos entre quem são "eles", diferentes do que somos "nós", que tipo de estrangeiro deve ser legitimamente autorizado a ingressar no país? E por quanto tempo deve ter permissão de permanência no território nacional| ${ }^{6}$ ?

2 HADDAD, Emma. The refugee in international society: between sovereigns.

3 ZOLBERG, Aristide. Matters of State: theorizing immigration policy.

4 NYERS, Peter. Rethinking refugees: beyond states of emergency; MARFLEET, Philip. Refugees in a global era; ARENDT, Hannah. As origens do totalitarismo.

5 BAUMAN, Zygmunt. Vidas desperdiçadas; SAYAD, Abdelmalek. A imigração ou os paradoxos da alteridade.

6 PRICE, Matthew. Rethinking asylum: history, purpose, and limits. 
A categoria de refugiado carrega em si as noções de transitoriedade, provisoriedade e temporalidade. Os refugiados se situam entre o país de origem e o país de destino. Ao transitar entre os dois universos, ocupam posição marginal, tanto em termos identitários, culturais e sociais, assentada na falta de pertencimento pleno enquanto membros da comunidade receptora e nos vínculos introjetados por códigos partilhados com a comunidade de origem; quanto em termos jurídicos, ao deixar de exercitar, ao menos em caráter temporário, o status de cidadão no país de origem e portar o status de refugiado no país receptor ${ }^{7}$.

A construção da definição jurídica e política de refugiado remonta ao contexto da Europa do pós-guerra. A partir da Convenção Relativa ao Estatuto dos Refugiados de 1951, cunhou-se o termo refugiado como aquele que possui fundado temor de perseguição por razões de raça, religião, nacionalidade, filiação em certo grupo social ou opiniões políticas ${ }^{8}$. O direito de o indivíduo perseguido em seu país de origem buscar asilo - ao transpor fronteiras, deslocar-se para outro país e solicitar-lhe proteção -, todavia, distingue-se do direito ao asilo, ou seja, à concessão desta proteção pelo país de destino ${ }^{9}$. Tal concessão constitui uma decisão soberana, relacionada ao controle sobre território e população, bem como sobre acesso e permanência de estrangeiros. Dessa forma, como já afirmado, não só os refugiados, como também o instituto do refúgio estão ancorados na lógica e dinâmica estatal.

A decisão estatal de reconhecer e receber refugiados envolve, sem dúvida, múltiplos e complexos fatores, abarcando tanto política externa como doméstica. O país receptor pode utilizar o acolhimento de refugiados como instrumento para deslegitimar o país de origem, ao rotulá-lo como perseguidor, repressor ou violador de direitos humanos. Pode favorecer a entrada de refugiados de determinadas origens, em virtude de questões sociais, étnicas, culturais, políticas ou econômicas, em detrimento de outras. Pode também perceber a presença dos refugiados, sobretudo em grande contingente, como pesado encargo socioeconômico ou como ameaça à segurança ou à identidade nacional ${ }^{10}$.

O estatuto de refugiado constitui uma condição jurídica, em tese, provisória. Os refugiados fugiram de seus países em função de eventos políticos (como guerras civis, regimes repressivos, entre outras situações de instabilidade política e violações de direitos humanos) e, uma vez findados, os cidadãos deveriam ser repatriados. Contudo, muitas vezes, esses fatores se arrastam por anos ou décadas, enquanto os refugiados buscam meios e estratégias para restabelecer suas vidas, (re)construindo relações sociais e laços afetivos, constituindo, por vezes, famílias

SAYAD, op. cit.; BAUMAN, op. cit.; HADDAD, op. cit.

8 ACNUR. Convenção Relativa ao Estatuto dos Refugiados.

9 ANDRADE, José Henrique Fischel de. Breve reconstituição histórica da tradição que culminou na proteção internacional dos refugiados.

${ }^{10}$ LOESCHER, op. cit.; WEINER, Myron. The Global Migration Crisis: challenge to States and Human Rights. 
nos países de destino. Esses fatores dificultam o regresso dos refugiados à sua terra natal e acarretam implicações em meio às comunidades e aos países acolhedores.

A gestão dos fluxos de refugiados envolve ainda a atuação das organizações internacionais, que buscam o compromisso estatal, mas, para obtê-lo, precisam negociar com as autoridades governamentais a partir de condições postas por elas. A fim de viabilizar operações e programas de assistência a refugiados, as organizações se valem de parcerias com ONGs locais ou internacionais. Nesse ponto, destaca-se a atuação do Alto Comissariado das Nações Unidas para os Refugiados (ACNUR), a agência especializada da ONU criada no mesmo contexto em que se deu a aprovação da Convenção relativa aos refugiados, no âmbito do pós-guerra.

A agência se empenha em concretizar soluções em prol do grupo, tidas como temporárias - como a instalação em campos - ou 'duráveis', por meio do repatriamento, do reassentamento e da integração local. No entanto, tais soluções podem se revelar, na prática, não tão duradouras como se esperava - trazendo à tona dificuldades em torno de sua implementação e efetividade.

Um ponto relevante a esse respeito se refere à ausência de participação dos próprios refugiados no processo de elaboração, execução e avaliação dos programas e das políticas a eles destinados. Como se pode notar, os refugiados são tratados como um problema que deve ser gerido e demanda soluções a serem tomadas, envolvendo a participação e articulação entre diversos atores, estatais e não estatais, internacionais e nacionais (especialmenteo Estado receptor, o ACNUR e as ONGs). Todavia, os próprios refugiados não foram devidamente reconhecidos como atores, capazes de influenciar as decisões que afetam diretamente suas vidas ${ }^{11}$ - o que pode comprometer o 'sucesso' do chamado processo de integração local.

\section{Integração local à luz do debate conceitual}

O termo 'integração local' faz referência ao processo que se desenvolve quando o refugiado passa a interagir em novo contexto, no país de destino, em meio à comunidade receptora. $\mathrm{O}$ debate conceitual em torno do que constitui integração, quais fatores devem ser considerados para aferi-la é um campo bastante fértil, ensejando diversas definições e abordagens teóricas e metodológicas entre pesquisadores dedicados ao estudo sobre o tema dos refugiados ${ }^{12}$.

Kuhlman ${ }^{13}$ a define como o processo mediante o qual os refugiados mantêm sua própria identidade, mas se tornam parte da sociedade acolhedora à medida que

11 NEEDHAM, Robin. Refugee participation: what is it, and why is it important for those who work with refugees, and for refugees themselves? Some comments and observations; CLARK, Lance. Promoting refugee participation in assistance projects.

12 CASTLES, Stephen et alii. Integration: mapping the field; SMITH, Gary; STUART, Emma; DA LOMBA, Sylvie. Introduction: Critical Reflections on Refugee Integration: Lessons from International Perspectives.

${ }^{13}$ KUHLMAN, Tom. The Economic Integration of Refugees in Developing Countries: a research model. 
possam conviver juntos com a população local de modo aceitável. O conceito de integração local, para o autor - assim como para Crisp ${ }^{14}$-, não significa assimilação dos refugiados na sociedade em que passam a viver, ou seja, não se espera que eles abandonem sua própria cultura, tornando-se indistinguíveis da comunidade local. A ideia é que nacionais e estrangeiros possam ajustar seus comportamentos e atitudes entre si, demandando um esforço dos nacionais para entender o diferente e o direito do estrangeiro de preservar seu repertório cultural de origem ${ }^{15}$.

Tal abordagem concebe a integração como via de mão dupla, a qual supõe adaptação não apenas do recém-chegado como também da sociedade receptora. Isso implica mudança em termos de valores, normas, comportamentos tanto para os refugiados quanto para os membros da comunidade local. Ao mesmo tempo, faz-se necessário propiciar o acesso a serviços e oportunidades de empregos, assim como a aceitação dos refugiados em termos de interação social, e aquisição de direitos, inclusive políticos. Essa visão se opõe àquela voltada para assimilação, mediante a qual se espera que os refugiados descartem sua cultura, tradição, língua de origem, devendo se integrar na sociedade receptora sem qualquer acomodação recíproca ${ }^{16}$.

Ager e Strang ${ }^{17}$ igualmente concebem a integração como um processo dialético entre refugiados e sociedade receptora. Para os autores, seus elementos centrais se referem à aquisição e acesso a emprego, moradia, educação e saúde; cidadania e direitos; processos de relações sociais com grupos dentro da comunidade receptora, tornando-se crucial identificar também as barreiras estruturais a essas relações em função da língua, da cultura e do ambiente local.

Tal processo é concebido por vários teóricos ${ }^{18}$ Como altamente complexo e desafiador, sobretudo por se configurar como multidimensional. Diversas esferas merecem ser consideradas, entre as quais: a social, a cultural, a étnica, a religiosa, a econômica, a política, a psicológica, a espacial.

Nesse sentido, ao problematizar a questão, Castles et alii ${ }^{19}$ levantam pertinentes indagações: afinal, do que está se falando: integração em quê? Quais são os critérios estabelecidos para aferir o 'sucesso' da integração? Segundo o mapeamento feito pelos autores, a integração é tida pela literatura especializada sobretudo em termos de seus aspectos práticos ou funcionais. Partindo da ideia de que o estatuto de refugiado implica o direito à proteção, desdobram-se aspectos ligados à provisão e ao acesso a serviços sociais para

\footnotetext{
${ }^{14}$ CRISP, Jeff. The local integration and local settlement of refugees: a conceptual and historical analysis.

${ }^{15}$ ONU. International migration policies.

${ }^{16}$ CASTLES et alii, op. cit.

17 AGER, Alastair; STRANG, Alison. Understanding integration: a conceptual framework.

${ }^{18}$ KUHLMAN, op. cit.; CRISP, op. cit.; CASTLES et alii, op. cit; AGER, STRANG, op. cit.

${ }^{19}$ CASTLES et alii, op. cit.
} 
viabilizar o processo de integração (como assistência à moradia, aprendizado da língua, educação, acesso ao mercado de trabalho, etc.). No entanto, para eles, a integração denominada de 'funcional' deve estar conectada a outras dimensões, como a interação mais ampla dos refugiados em meio à sociedade receptora e a plena participação em suas diversas esferas.

A integração deve ser entendida como um termo abrangente, abarcando um conjunto de processos em múltiplas esferas, cada qual possuindo seu próprio modo de operação e significado, desenrolando-se em temporalidades e trajetórias que lhes são peculiares e produzindo resultados variáveis. É possível, assim, que os refugiados tenham acesso ao mercado de trabalho, mas, ao mesmo tempo, sejam excluídos ou tenham desvantagem na área de educação. Podem ser incluídos em ambas as áreas, mas serem excluídos em termos de participação política. Ou ainda, incluídos nessas diversas áreas, mas excluídos em termos culturais, identitários ou outras formas cotidianas de interação social ${ }^{20}$.

A perspectiva funcionalista acerca da integração sugere que os refugiados devem ser integrados aos programas ou políticas de integração existentes no país receptor. Espera-se que eles se conformem de uma determinada maneira prescrita. Tal expectativa pode colocar em risco as possibilidades em termos de escolha, empoderamento e do próprio desenvolvimento dos refugiados, os quais não possuem voz no processo que determina seu bem-estar e suas oportunidades de vida. Além disso, as condições para a integração dos refugiados também pressupõem uma sociedade receptora de fato acolhedora e receptiva - o que nem sempre se verifica na realidade ${ }^{21}$.

O conceito de integração, portanto, é visto como bastante controverso, sendo considerado por muitos teóricos como problemático, vago e incerto ${ }^{22}$. Uma questão crucial emergente desse debate é: quem define o que significa integração? Ou seja, quais atores prevalecem em estabelecer seu conteúdo e semeá-lo discursivamente, bem como quais esferas são privilegiadas a partir dessa interpretação (como ocorre, p.ex., frequentemente com a integração econômica em relação à cultural, social ou política).

Importa pensar a integração, nesse sentido, também a partir dos atores envolvidos nesse processoe das estruturas institucionais - incluindo legislações, programas e políticas nacionais ${ }^{23}$. É fato que os programas e as políticas voltadas para a integração em seus diversos aspectos dependem de instituições e decisões

\footnotetext{
${ }^{20}$ Ibidem.

${ }^{21}$ Ibidem.

22 Ibidem; AGER, STRANG, op. cit.; SMITH, STUART, DA LOMBA, op. cit.

${ }^{23}$ SIGONA, Nando. Refugee integration(s): policy and practice in the European Union; VAN TURBENGEN, Frank. Immigrant integration: a cross-national study; REITZ, Jeffrey G. (ed.). Host societies and the reception of immigrants.
} 
governamentais. Além das agências burocráticas estatais, destaca-se a atuação de ONGs, instituições religiosas e privadas, no âmbito doméstico, e de organizações internacionais. Contudo, não raro, aponta-se o desconhecimento por parte destes atores sobre as reais necessidades dos refugiados, suas dificuldades de acesso a serviços e concretização de direitos - razão pela qual entende-se fundamental ouvir suas demandas e percepções sobre os processos de integração vivenciados por eles ${ }^{24}$.

Ao tomar a integração como processo de via dupla, há que se abrir espaço para os refugiados se manifestarem a respeito de como o percebem em suas múltiplas dimensões e sobre os objetivos que os programas e as políticas nas diversas áreas devem alcançar. Os critérios a serem utilizados para definir o 'sucesso' desse processo multidimensional também devem incorporar os olhares dos próprios refugiados. Vale dizer, eles merecem ser integrados às discussões sobre integração, tanto no desenho dos programas e das políticas, quanto em sua implementação e futura avaliação.

Smith, Stuart e Da Lomba ${ }^{25}$ ressaltam que o tema da integração de refugiados é ainda pouco explorado na literatura especializada e apontam para a necessidade de se avançar teórica e empiricamente em diferentes direções - entre as quais destacamos a importância de se pesquisar mais a fundo as experiências dos próprios refugiados acerca dos processos de integração e exclusão social vivenciados por eles e de se adotar uma perspectiva interdisciplinar para melhor compreensão desse fenômeno extremamente rico e multifacetado.

Em que pesem os vários questionamentos acima suscitados e o reconhecimento de que é preciso aprofundar as reflexões teóricas e metodológicas acerca da integração de refugiados, o enfoque dado aqui a tal processo recai sobre a estrutura institucional doméstica, contemplando os atores estatais e não estatais que dela participam, assim como as condições de vida desses migrantes internacionais no país.

\section{Refugiados no Brasil: estrutura institucional, atores e condições de vida}

No Brasil, a parceria entre o ACNUR e as instituições religiosas (sobretudo as Cáritas, que fazem parte da Igreja Católica) com o intuito de fornecer assistência a refugiados remota à época do regime militar, no final dos anos 1970. Com o processo de redemocratização em meados dos anos 1980, abriram-se novas possibilidades rumo a um compromisso internacional e doméstico em relação às temáticas dos direitos humanos e dos refugiados. O tema dos refugiados foi inserido na pauta do tema mais amplo dos direitos humanos na segunda metade dos anos 1990, a partir de articulações desses atores não-estatais de atuação doméstica e internacional, as

\footnotetext{
${ }^{24}$ CASTLES et alii, op. cit.

${ }^{25}$ SMITH, STUART, DA LOMBA, op. cit.
} 
quais foram bem sucedidas por se conjugarem a interesses governamentais ligados à política externa e interna ${ }^{26}$. Assim, o primeiro Programa Nacional de Direitos Humanos de 1996 previa, entre suas metas, a elaboração de projeto de lei para regulamentar o estatuto dos refugiados como proposta de ação de curto prazo ${ }^{27}$.

O processo de institucionalização do tema dos refugiados no Brasil se constituiu com base na aprovação de uma legislação nacional específica (Lei n. 9.474/97), a qual trouxe uma série de provisões, dentre elas a definição do termo refugiado, que contemplava não apenas aquela da Convenção da ONU, mas também a chamada definição ampliada trazida pela Declaração de Cartagena. Entre as inovações, estava o direito de reunião familiar, estendendose a concessão do refúgio aos demais membros da família do refugiado. Outra provisão importante consistia no direito de trabalhar no país ainda na condição de solicitante de refúgio, antes da decisão final sobre o reconhecimento do estatuto de refugiado ${ }^{28}$. Tanto o solicitante como os membros de sua família têm permissão de residência provisória no país, recebendo documentos provisórios de identidade após a propositura do pedido de refúgio ${ }^{29}$.

A lei brasileira também criou o Comitê Nacional para os Refugiados (CONARE), formado por representantes dos Ministérios da Justiça (MJ), das Relações Exteriores, do Trabalho, da Saúde, da Educação, do Departamento da Polícia Federal e da sociedade civil (representada pelas instituições religiosas), todos com direito a voto. O representante do ACNUR também se faz presente, com direito a voz. O arranjo institucional do CONARE consolidou a chamada estrutura tripartite, reunindo os principais atores envolvidos com os refugiados no Brasil: instituições religiosas (Cáritas e IMDH - Instituto Migrações e Direitos Humanos), organização internacional (ACNUR) e governo brasileiro (representado por seus órgãos no colegiado, com destaque para o MJ, que o preside). As atribuições do Comitê contemplam: julgar em primeira instância os pedidos de refúgio, ou seja, realizar o processo de elegibilidade pelo qual se reconhece o estatuto de refugiado; determinar a perda e cessação da condição de refugiado; além de "orientar e coordenar ações necessárias à eficácia da proteção, assistência e apoio jurídico aos refugiados"30.

O marco jurídico e institucional brasileiro relativo aos refugiados foi visto como inovador, de vanguarda, avançando sobretudo ao incluir a definição ampliada dada pela Declaração de Cartagena de 1984 (instrumento regional aplicado na América Latina), reconhecendo como refugiados pessoas que

\footnotetext{
${ }^{26}$ Para maiores detalhes, ver: MOREIRA, Julia Bertino. Política em relação aos refugiados no Brasil (1947-2010). Tese de doutorado apresentada ao Programa de Pós-Graduação em Ciência Política do Instituto de Filosofia e Ciências Humanas da UNICAMP. Campinas, 2012.

27 BRASIL. Programa Nacional de Direitos Humanos I.

${ }^{28}$ JUBILUT, Liliana Lyra. Refugee Law and Protection in Brazil: a model in South America?

${ }^{29}$ BRASIL. Lei n. 9.474 de 22 de julho de 1997.

30 Ibidem.
} 
fugiram de seus países em decorrência de graves violações de direitos humanos. Outro ponto de contribuição se referia à composição do CONARE, que abarcava a participação de atores da sociedade civil com direito a voto.

A legislação brasileira ainda incorporou as chamadas soluções duráveis para os refugiados, frisando o seu caráter voluntário: o repatriamento, o reassentamento e a integração local. A respeito desta, no entanto, nos dispositivos jurídicos, apenas foram tratadas questões sobre documentação, incluindo documentos relativos à educação ${ }^{31}$. Não foram especificados, portanto, os termos para concretizar a integração, em seus mais diversos aspectos (psicológicos, sociais, culturais, econômicos, políticos), bem como as condições de vida a serem proporcionadas aos refugiados após o ingresso no país. Tampouco foi previsto o acesso a políticas públicas a esses migrantes internacionais ${ }^{32}$.

A integração local, como já indicado, constitui um processo complexo que abrange múltiplos fatores, entre os quais socioeconômicos, culturais e políticos. É preciso propiciar ao refugiado oportunidades de emprego, moradia, aprendizado da língua, utilização de serviços públicos, especialmente de saúde e educação. Outro ponto fundamental se refere à construção de relações sociais com os membros da comunidade local.

As iniciativas voltadas para a integração dos refugiados no Brasil são levadas a cabo preponderantemente pela sociedade civil ${ }^{33}$, embora haja também participação do ACNUR e do Estado brasileiro nesse processo (o que remete à interação entre atores estatais e não estatais na chamada estrutura tripartite). As instituições religiosas ajudaram a construir uma extensa rede de apoio aos refugiados no país, com base em parcerias com outras instituições públicas e privadas.

Tanto solicitantes de refúgio quanto refugiados reconhecidos pelo processo de elegibilidade são auxiliados por estas instituições, em termos de proteção jurídica e assistência no país ${ }^{34}$. O direito à saúde é garantido mediante o atendimento médico em hospitais públicos e fornecimento de medicamentos adquiridos com verba do ACNUR. Já o direito à educação é propiciado pelo ingresso em escolas e universidades públicas. A alimentação e moradia são fornecidas a partir de convênios firmados com instituições da citada rede de apoio aos refugiados no país. Contudo, direitos políticos não foram assegurados

\footnotetext{
31 Ibidem.

32 JUBILUT, op. cit.

${ }^{33}$ Vale registrar que mais de $60 \%$ do orçamento total destinado aos programas de integração local dos refugiados no país é oriundo das instituições da sociedade civil (cf. JUBILUT, Liliana Lyra. Enhancing refugees' integration: new initiatives in Brazil).

${ }^{34}$ SPRANDEL, Márcia Anita; MILESI, Rosita. O acolhimento a refugiados no Brasil: histórico, dados e reflexões; NOGUEIRA, Maria Beatriz; MARQUES, Carla Cristina. Brazil: ten years of refugee protection.
} 
aos refugiados, que se encontram privados de exercer o direito de voto em nível municipal, estadual ou federal, o que prejudica consideravelmente a capacidade de terem suas demandas ouvidas e atendidas no país.

Adentrando o tripartidarismo que marca a estrutura voltada para a integração dos refugiados no país, é relevante pensar no papel desempenhado por cada ator. O governo brasileiro fornece serviços básicos universais (como saúde e educação), disponíveis à população local. A sociedade civil, representada por instituições religiosas, atuando também através de acordos com ONGs e diversas instituições, oferece serviços essenciais, como auxílio à alimentação, cursos para aprendizado do idioma local, cursos profissionalizantes que facilitam a inserção no mercado de trabalho e moradia, entre outros. O ACNUR, por sua vez, destina recursos para financiar o auxílio concedido através das Cáritas e também fornece expertise e colaboração técnica para os programas implementados em prol do grupo.

Porém, ainda que exista uma estrutura arquitetada para facilitar o processo de integração local dos refugiados no país, inúmeros desafios se colocam, sobretudo em termos das condições de vida desses migrantes. Interessa conhecer, nessa medida, as características socioeconômicas dos refugiadose a avaliação sobre o apoio dos atores que atuam em prol deles no país.

Com base nos dados obtidos pela pesquisa sobre Condições de Vida da População Refugiada no Brasil ${ }^{35}$, a maioria dos refugiados residentes em São Paulo e Rio de Janeiro em 2007 era do sexo masculino, solteiro, jovem e fazia parte da classe C. Apenas 2,8\% dos entrevistados participavam de programa governamental (em específico, o Bolsa Família), enquanto 11\% recebiam auxílio financeiro subsidiado pelo ACNUR. Em relação à moradia, a maioria dos entrevistados residia em habitação particular, permanente e alugada. Quanto à documentação, $60,6 \%$ dos entrevistados afirmaram não ter problemas nesse quesito, ao passo que $28,1 \%$ responderam que havia demora na confecção do $\mathrm{RNE}^{36}$.

No que diz respeito ao grau de instrução, a maioria dos entrevistados possuía entre 9 e 12 anos de estudos, sendo que 37,6\% frequentava escola ou creche. De $61,9 \%$ que não frequentava, $29,6 \%$ não o fazia por não ter tempo ou trabalhar no horário, enquanto 19,1\% já havia concluído os estudos ou não pretendia mais estudar, 3,7\% afirmou que não tinha vaga e 5,2\% não possuía a documentação necessária. No quesito saúde, 51,3\% dos refugiados procuravam o hospital mais próximo de sua casa para serem atendidos e 84,2\% não possuíam plano de saúde. Em termos

35 A pesquisa foi realizada em 2007, coordenada pela Profa. Dra. Rosana Baeninger, do NEPO/UNICAMP, em parceria com o ACNUR, as Cáritas Arquidiocesanas de São Paulo e Rio de Janeiro e com financiamento da Secretaria Especial de Direitos Humanos. Baseou-se na aplicação de questionários, a partir de entrevistas realizadas com refugiados residentes nas duas capitais brasileiras. As entrevistas foram realizadas nas sedes das Cáritas. Para maiores informações sobre a pesquisa, consultar os artigos citados a seguir.

${ }^{36}$ BAENINGER, Rosana (coord.). População Refugiada: retrato das condições de vida das famílias em São Paulo e Rio de Janeiro. 
de assistência médica, 23,2\% dos entrevistados passavam por acompanhamento e $22,7 \%$ faziam uso contínuo de medicamento. Com relação a trabalho, quando as entrevistas foram realizadas, $56,4 \%$ dos refugiados estavam trabalhando, sendo que apenas 32,8\% tinham carteira de trabalho assinada pelo empregador ${ }^{37}$.

O banco de dados da pesquisa revelou que as condições de trabalho e os níveis salariais foram avaliados pelos entrevistados, de modo geral, como insatisfatórios. O acesso aos serviços públicos também foi considerado precário, principalmente em termos de saúde e moradia. Apontou-se ainda a dificuldade no reconhecimento de certificados e diplomas universitários. Outro ponto relevante foi que $53,4 \%$ da população residente em São Paulo se declarou insatisfeita ou muito insatisfeita a respeito de discriminação ${ }^{38}$. Frequentemente associados a 'fugitivos', grande parte da população brasileira desconhecia quem eram os refugiados, o que pode ser visto como obstáculo aos processos de integração social, cultural e econômica (inclusive em termos de inserção no mercado de trabalho) ${ }^{39}$.

Os refugiadosainda avaliaram o apoio prestado pelas Cáritas Arquidiocesanas, pelo ACNUR e CONARE. Com relação à agência da ONU, 50,7\% dos entrevistados consideraram-no insuficiente, indicando como ponto negativo sobretudo o valor e o corte do auxílio financeiro fornecido. A Cáritas de São Paulo foi bem avaliada, já que $63,3 \%$ reputaram o apoio suficiente. Situação praticamente inversa se verificou com a Cáritas do Rio de Janeiro, sendo o apoio tido como insuficiente por $59,7 \%$ dos entrevistados. No caso do CONARE, desponta o fato de que 35,7\% não responderam, não souberam dizer ou não conheciam a instituição.

Alguns problemas colocados pelos refugiados são também enfrentados pela população local, uma vez que se relacionam a questões estruturais mais amplas relacionadas à realidade socioeconômica do país. Todavia, as dificuldades com que se deparam os refugiados são agravadas, por se tratar de uma população estrangeira, o que gera maiores empecilhos para garantir o acesso e a concretização de direitos no Brasil. Ademais, as entrevistas apontam para a necessidade de se aprimorar o apoio prestado pelas instituições que atuam em prol do grupo e de se buscar conferir maior efetividade à estrutura voltada para integração local no país.

\section{Reflexões finais}

Tratar a categoria dos refugiados como um 'problema' a ser administrado e resolvido a partir da lógica soberana estatal no sistema internacional reforça uma perspectiva que se furta a reconhecê-los como sujeitos capazes de influir

\footnotetext{
37 Ibidem; AYDOS, Mariana Recena; BAENINGER, Rosana; DOMINGUEZ, Juliana. Condições de Vida da População Refugiada no Brasil: trajetórias migratórias e arranjos familiares.

${ }^{38}$ BAENINGER, Rosana; DOMINGUEZ, Juliana; AYDOS, Mariana Recena. Condições de Vida da População Refugiada no Brasil: divulgação da pesquisa de campo e resultados preliminares.

${ }^{39}$ MOREIRA, Julia Bertino; BAENINGER, Rosana. Local integration of refugees in Brazil.
} 
sobre os rumos de suas vidas no país receptor. Ao mesmo tempo, tal perspectiva possibilita maior controle por parte de atores estatais e não estatais sobre os próprios refugiados e os contornos a serem conferidos ao processo de integração local. Encontra-se a cargo de tais atores a definição do significado da integração, assim como dos critérios mediante os quais se pode aferir seu sucesso. Todavia, amparando-se na discussão trazida pela literatura especializada, revela-se indispensável integrar os refugiados nesse processo de debate e decisão sobre os termos da integração local, dar voz ao grupo, possibilitando que eles participem e interajamefetivamente com os demais atores.

Partindo do debate conceitual apresentado, a integração local enquanto "solução duradoura" constitui um fenômeno muito mais amplo e complexo dialético, multidimensional e multiprocessual - do que aparentemente se supõe. Ao analisarmos esse processo no Brasil, há dificuldades em diversas esferas da integração, tanto em termos "funcionais" quanto políticos e de interação social e cultural. Problemas se colocam no tocante ao acesso a serviços públicos (como saúde e educação) e programas sociais, condições de trabalho, além do sentimento de discriminação identificado por refugiados que vivem no país. Somam-se a eles a ausência de integração plena na esfera política. Maiores esforços merecem ser envidados, portanto, para tornar tal estrutura institucional mais efetiva, fortalecer o apoio proporcionado pelos atores envolvidos e, acima de tudo, aprimorar as condições de vida aos refugiados aqui acolhidos.

Por fim, destaca-se a relevância de se ampliar a discussão e se produzir mais pesquisas de cunho teórico-conceitual, metodológico e empírico sobre a integração de refugiados - sobretudo no Brasil, onde o tema é incipiente e vem se constituindo uma comunidade acadêmica a ele dedicada. As contribuições seriam de fato enriquecedoras se conseguissem explorar as percepções, perspectivas e experiências dos próprios refugiados a fim de captar como os processos de integração são vivenciados por esses sujeitos. Somente assim, a partir de suas vozes e seus olhares, será possível conhecer e compreender mais densamente tal fenômeno no país.

\section{Referências bibliográficas}

ACNUR. Convenção Relativa ao Estatuto dos Refugiados. In IDEM. Manual de procedimentos e critérios a aplicar para determinar o estatuto de refugiado. Lisboa: ACNUR, 1996.

AGER, Alastair; STRANG, Alison. Understanding integration: a conceptual framework. Journal of Refugee Studies, v. 21, n. 2, 2008, p. 166-191.

ANDRADE, José Henrique Fischel de. Breve reconstituição histórica da tradição que culminou na proteção internacional dos refugiados. In ARAUJO, Nadia; ALMEIDA, Guilherme Assis de (coord.). O Direito Internacional dos Refugiados: uma perspectiva brasileira. Rio de Janeiro: Renovar, 2001, p. 99-125.

ARENDT, Hannah. As origens do totalitarismo. São Paulo: Companhia das Letras, 1989. 
AYDOS, Mariana Recena; BAENINGER, Rosana; DOMINGUEZ, Juliana. Condições de Vida da População Refugiada no Brasil: trajetórias migratórias e arranjos familiares. III Congresso da Associação Latino-Americana de População. Córdoba, 2008.

BAENINGER, Rosana (coord.). População Refugiada: retrato das condições de vida das famílias em São Paulo e Rio de Janeiro. Campinas: NEPO/ UNICAMP, 2008.

BAENINGER, Rosana; DOMINGUEZ, Juliana; AYDOS, Mariana Recena. Condições de Vida da População Refugiada no Brasil: divulgação da pesquisa de campo e resultados preliminares. Anais do V Encontro Nacional de Migrações. Campinas: Nepo/Unicamp, 2007.

BAUMAN, Zygmunt. Vidas desperdiçadas. Rio de Janeiro: Jorge Zahar, 2005.

BRASIL. Programa Nacional de Direitos Humanos I. 1996. Disponível em: <http:// www.planalto.gov.br>. Acesso em: 10.10.2009.

. Lei n. 9.474 de 22 de julho de 1997. In ACNUR; IMDH. Lei 9.474/97 e Coletânea de Instrumentos de Proteção Internacional dos Refugiados. Brasília, 2010.

CASTLES, Stephen; KORAC, Maja; VASTA, Ellie; VERTOVEC, Steven. Integration: mapping the field. London: Home Office Immigration Research and Statistics Service, 2002.

CLARK, Lance. Promoting refugee participation in assistance projects. Washington DC: Refugee Policy Group, 1987.

CRISP, Jeff. The local integration and local settlement of refugees: a conceptual and historical analysis. New Issues in Refugee Research. Geneva: UNHCR, 2004.

HADDAD, Emma. The refugee in international society: between sovereigns. Cambridge: Cambridge University Press, 2008.

JUBILUT, Liliana Lyra. Enhancing refugees' integration: new initiatives in Brazil. Forced Migration Review, v. 35, 2010, p. 46-47.

. Refugee Law and Protection in Brazil: a model in South America? Journal of Refugee Studies, v. 19, n. 1, 2006, p. 22-44.

KUHLMAN, Tom. The Economic Integration of Refugees in Developing Countries: A Research Model. Journal of Refugee Studies, Oxford, v. 4, n. 1, 1991, p. 1-20.

LOESCHER, Gil. Beyond Charity: international cooperation and the global refugee crisis. New York: Oxford University Press, 1996.

MARFLEET, Philip. Refugees in a global era. Basingstoke: Palgrave Macmillan, 2006.

MOREIRA, Julia Bertino; BAENINGER, Rosana. Local integration of refugees in Brazil. Forced Migration Review, v. 35, 2010, p. 48-49.

NEEDHAM, Robin. Refugee participation: what is it, and why is it important for those who work with refugees, and for refugees themselves? Some comments and observations. Paper prepared for PARINAC Conference, Addis Ababa, March 1994.

NOGUEIRA, Maria Beatriz; MARQUES, Carla Cristina. Brazil: ten years of refugee protection. Forced Migration Review, v. 30, 2008, p. 57-58.

NYERS, Peter. Rethinking refugees: beyond states of emergency. New York; London: Routledge, 2005.

PRICE, Matthew. Rethinking asylum: history, purpose, and limits. Cambridge: Cambridge University Press, 2009. 
REITZ, Jeffrey G. (ed.). Host societies and the reception of immigrants. La Jolla, CA: Center for Comparative Immigration Studies, University of California, San Diego, 2003.

ONU. International migration policies. New York: ONU, 1998.

SAYAD, Abdelmalek. A imigração ou os paradoxos da alteridade. São Paulo: Edusp, 1998. SIGONA, Nando. Refugee integration(s): policy and practice in the European Union. Refugee Survey Quarterly, v. 24, n. 4, 2005, p. 115-122.

SMITH, Gary; STUART, Emma; DA LOMBA, Sylvie. Introduction: Critical Reflections on Refugee Integration: Lessons from International Perspectives. Journal of Refugee Studies, v. 23, n. 4, 2010, p. 411-414.

SPRANDEL, Márcia Anita; MILESI, Rosita. O acolhimento a refugiados no Brasil: histórico, dados e reflexões. In MILESI, Rosita (org.). Refugiados: realidade e perspectivas. Brasília: CSEM/IMDH, 2003, p. 113-134.

VAN TURBENGEN, Frank. Immigrant integration: a cross-national study. New York: LFB Scholarly Pub. LLC, 2006.

ZOLBERG, Aristide. Matters of State: theorizing immigration policy. In HIRSCHMAN, Charles; KASINITZ, Philip; DEWIND, Josh (eds.). The handbook of international migration: the American experience. New York: Russell Sage foundation, 1999.

WEINER, Myron. The Global Migration Crisis: challenge to States and Human Rights. New York: Harper Collins College Publishers, 1995.

\section{Abstract}

\section{Refugees in Brazil: reflections on the local integration process}

The article aims to reflect on the process of local integration of refugees in Brazil. It begins discussing the category of refugees which is treated as a problem demanding solutions to be implemented by the State and nonState actors. Moreover, it briefly presents the conceptual debate regarding integration, shedding light on different perspectives to understand it. The focus on the local integration of refugees in Brazil emphasized the institutional structure in the country, the actors involved in this process and the living conditions of refugees in Brazil. The conclusion highlights the necessity of improvement and more effectiveness of this structure and the work of the actors involved in this process, which also requires more refugee participation.

Keywords: refugees, local integration, Brazil.

Recebido para publicação em 17/09/2014.

Aceito para publicação em 11/11/2014. Received for publication in September, $17^{\text {th }}, 2014$. Accepted for publication in November, 11 $11^{\text {th }}, 2014$. 